\title{
LUMINESCENCE STUDY OF ZnSe BASED SCINTILLATORS IN FREQUENCY DOMAIN
}

\author{
P. Vitta ${ }^{\text {a }}$, G. Tamulaitis ${ }^{\text {a }}$, D. Shevchenko ${ }^{\text {a }}$, A. Žukauskas ${ }^{\text {a }}$, N. Starzhinskiy ${ }^{\text {b }}$, \\ K. Katrunov ${ }^{\mathrm{b}}$, and V. Ryzhikov ${ }^{\mathrm{b}}$ \\ ${ }^{a}$ Institute of Materials Science and Applied Research, Vilnius University, Saulètekio 9, LT-10222 Vilnius, Lithuania \\ E-mail: pranciskus.vitta@ff.vu.lt \\ ${ }^{\mathrm{b}}$ Institute for Scintillation Materials of National Academy of Sciences of Ukraine, 60 Lenin Ave., UA-61001 Kharkov, \\ Ukraine
}

Received 2 September 2008; accepted 18 September 2008

\begin{abstract}
Photoluminescence of ZnSe-based scintillation crystals is studied. Photoluminescence intensities and spectra of isoelectronically doped $\mathrm{ZnSe}(\mathrm{Te}), \mathrm{ZnSe}(\mathrm{O})$, and $\mathrm{ZnSe}(\mathrm{O}, \mathrm{Al})$ are compared. Frequency domain luminescence lifetime measurement technique was applied to study carrier dynamics at low density of nonequilibrium carriers, which is typical for operation of high-sensitivity ZnSe-based radiation detectors. Temperature-dependent competition between donor-acceptor-pair-type and exponential luminescence decay components was observed.
\end{abstract}

Keywords: scintillator, radiation detectors, photoluminescence spectroscopy

PACS: $29.40 . \mathrm{Mc}, 78.47 . \mathrm{Cd}, 78.55 . \mathrm{Et}$

\section{Introduction}

Zinc selenide attracted considerable attention as a wide-band-gap semiconductor for light emitting diodes and laser diodes. However, the lifetime of these devices was insufficient for use of $\mathrm{ZnSe}$ in commercial applications. Meanwhile, attempts of using $\mathrm{ZnSe}$ as scintillator material have been quite successful [1-3]. ZnSe exhibits high radiation hardness, conversion efficiency, and low hygroscopicity, when compared with conventional scintillators like $\mathrm{CsI}(\mathrm{Tl})$, which are widely used in detectors for many low energy X-ray applications $[1,4]$. ZnSe-based scintillators can be successfully used in various applications in medicine, environment monitoring, and security.

$\mathrm{ZnSe}$ has strong defect-related luminescence resulting in emission of photons, which are weakly reabsorbed, since their energies are well below the band gap. Moreover, the emission spectrum (band is peaked at $\sim 600 \mathrm{~nm}$ ) is convenient for detection by highsensitivity photodiodes. Emission efficiency of this material can be improved by doping [5-9] and after-growth annealing $[6,10-12]$. Appropriate doping and thermal treatment enhance formation of stabile centres of efficient radiative emission. Isoelectronic doping with tellurium has been shown to substantially enhance the emission [6,7]. Meanwhile, the influence of other isoelectronic impurities attracted still much less attention. In the present study, we investigate deep-level-related emission of ZnSe crystals with three types of isoelectronic doping: $\mathrm{ZnSe}(\mathrm{Te}), \mathrm{ZnSe}(\mathrm{O})$, and $\mathrm{ZnSe}(\mathrm{O}, \mathrm{Al})$.

The defect-related emission of ZnSe scintillators consists of at least two spectral components $[6,10,13-$ 15]. Luminescence mechanisms in this spectral region and relationship of the emission parameters with conditions of growth, annealing, and doping are extensively studied, but still not fully understood. Photoluminescence is proved to be an informative tool for study of $\mathrm{ZnSe}$ scintillators. In particular, time-resolved photoluminescence study allows one to have an insight into the dynamics of recombination and transfer of nonequilibrium carriers in $\mathrm{ZnSe}$ [10,16-18]. However, to perform the usual time-resolved photoluminescence measurement, a pulsed excitation to initially quite high carrier densities is required. This might lead to saturation of certain channels of radiative or nonradiative recombination [10], which can be important in detectors operating in usual conditions of low excitation levels.

In the present study, application of frequency domain luminescence lifetime measurement (FDLM) technique enabled us to have extremely low excitation power densities. In addition, FDLM technique enables one to 
study the photoluminescence decay on a wide time range (from millisecond to subnanosecond domain, in our experiments). In order to reveal the recombination mechanisms in more detail, the luminescence was investigated in the range of temperatures from $95 \mathrm{~K}$ to room temperature.

\section{Experimental set-up}

The ZnSe crystals under study were grown by Bridgman-Stockbarger method in a vertical compression furnace. $\mathrm{ZnSe}(\mathrm{Te})$ sample contained $1 \mathrm{wt} \%$ of tellurium. Oxygen was introduced into $\mathrm{ZnSe}(\mathrm{O})$ sample by crushing an intentionally undoped $\mathrm{ZnSe}$ crystal, exposing the powder to oxygen environment, and using the oxygenated powder for regrowing the crystal. The $\mathrm{ZnSe}(\mathrm{O}, \mathrm{Al})$ sample was grown by adding $\mathrm{Al}_{2} \mathrm{O}_{3}$ in the raw material. A rough estimate of oxygen content is approximately at $0.01 \mathrm{wt} \%$ for both $\mathrm{ZnSe}(\mathrm{O})$ and $\mathrm{ZnSe}(\mathrm{O}, \mathrm{Al})$. All samples were annealed after their growth.

Photoluminescence was investigated at extremely low excitation power densities $\left(0.1 \mathrm{~W} / \mathrm{cm}^{2}\right)$. Nichia light emitting diode (LED) emitting at $375 \mathrm{~nm}$ was used for excitation. When applying the FDLM technique, the LED current was modulated in the range from $1 \mathrm{~Hz}$ to $250 \mathrm{kHz}$ to modulate the LED emission intensity. Difference in phase and modulation depth between excitation and luminescence signal was measured as a function of frequency $\omega$. Digital lock-in amplifier (Signal Recovery 7265) was used to measure the signal detected by high-speed photomultiplier (Hamamatsu H6780-01). The spectral region of interest was selected by using optical filters. The spectral window for detection was set up to include the entire deep-level luminescence band (from 500 to $800 \mathrm{~nm}$ ).

The phase shift $\phi$ and decrease in modulation depth $1 / \mu$ of the registered signal can be used for Fouriertransform-based extraction of luminescence decay function $I(t)$ in time domain by using the following relationships [19]:

$$
\phi(\omega)=\arctan \left(\frac{N_{\omega}}{D_{\omega}}\right), \quad \mu(\omega)=\frac{m}{M}=\sqrt{N_{\omega}^{2}+D_{\omega}^{2}} .
$$

Here $N_{\omega}$ and $D_{\omega}$ are sine and cosine transforms of the

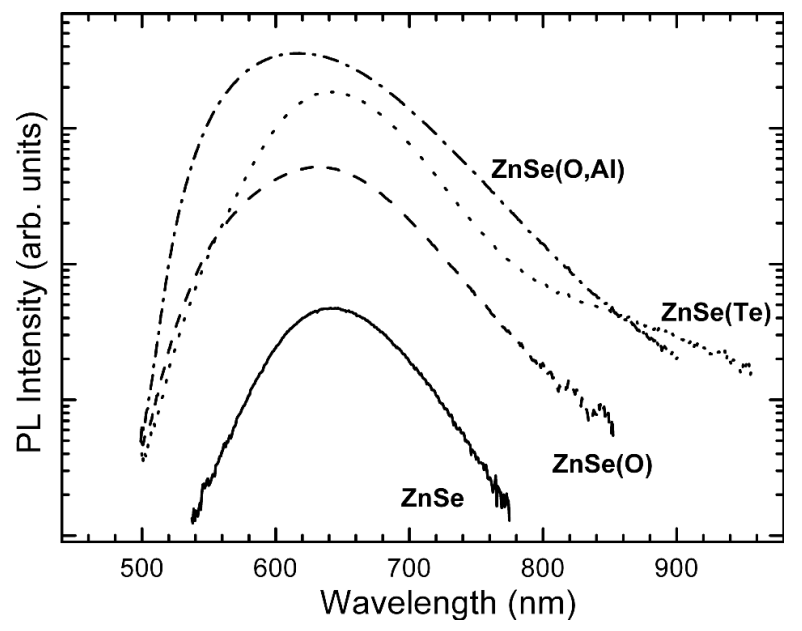

Fig. 1. Photoluminescence spectra of $\mathrm{ZnSe}$ (solid line), $\mathrm{ZnSe}(\mathrm{Te}$ ) (dotted line), $\mathrm{ZnSe}(\mathrm{O})$ (dashed line), and $\mathrm{ZnSe}(\mathrm{O}, \mathrm{Al})$ (dash dotted line) at room temperature.

intensity decay $I(t)$. In a general case, they can be expressed as

$N_{\omega}=\frac{\int_{0}^{\infty} I(t) \sin \omega t \mathrm{~d} t}{\int_{0}^{\infty} I(t) \mathrm{d} t}$ and $D_{\omega}=\frac{\int_{0}^{\infty} I(t) \cos \omega t \mathrm{~d} t}{\int_{0}^{\infty} I(t) \mathrm{d} t}$.

In the simplest case of a single exponential decay, the relationship of the decay time $\tau$ with $\phi$ and $\mu$ is straightforward:

$$
\tan \phi=\omega \tau \quad \text { and } \quad \mu=\left(1+\omega^{2} \tau^{2}\right)^{-1 / 2} .
$$

\section{Results and discussion}

The photoluminescence (PL) spectra of ZnSe samples with different isoelectronic doping are depicted in Fig. 1. Doping with tellurium (dotted curve) increases the luminescence intensity by a factor of $\sim 40$, as compared with undoped $\mathrm{ZnSe}$ (solid curve). The samples doped with oxygen (dashed curve) and oxygen together with aluminium (dash-dotted curve) demonstrate a spectral blueshift of 10 and $20 \mathrm{~nm}$ and an increase in intensity by one and two orders of magnitude, respectively. Such a large increase in photoluminescence intensity evidences good prospect for considerable enhancement of the radiative recombination through the deep impurity levels formed by applying appropriate doping. The highest photoluminescence intensity is achieved by co-doping $\mathrm{ZnSe}$ with oxygen and aluminium. Though aluminium can hardly act as an activator, introduction of this impurity seems to augment incorporation of oxygen into the $\mathrm{ZnSe}$ crystal and, 


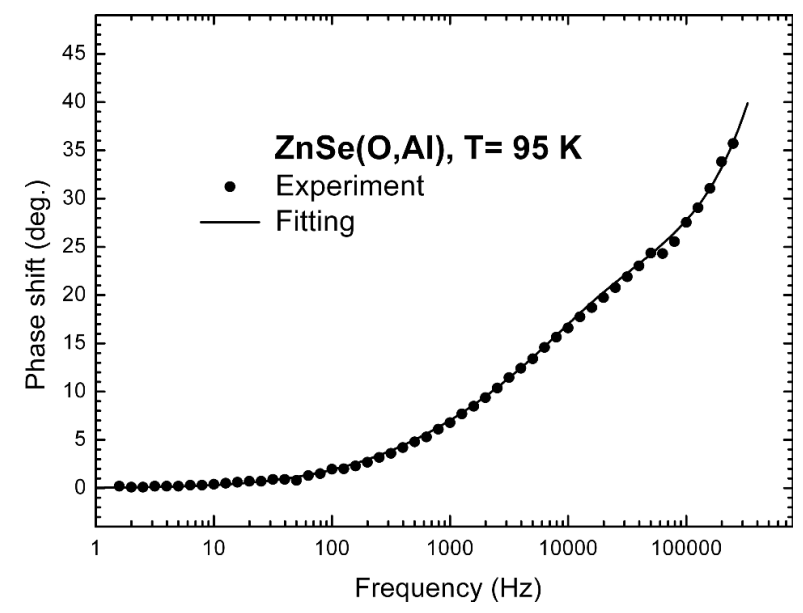

Fig. 2. Measured photoluminescence phase shift as a function of frequency in $\mathrm{ZnSe}(\mathrm{O}, \mathrm{Al})$ sample at temperature of $95 \mathrm{~K}$ (closed circles) and its fit (see text for details).

consequently, formation of higher density of the defect centres responsible for efficient emission.

The luminescence phase shift as a function of frequency for the sample $\mathrm{ZnSe}(\mathrm{O}, \mathrm{Al})$ is depicted in Fig. 2. The function in the entire frequency range corresponds to nonexponential luminescence decay. The experimental data were fitted by a function consisting of two terms. Since at least a part of luminescence under study occurs as a result of donor-acceptor pair (DAP) recombination, one term describes this type of recombination. The DAP recombination rate $W(R)$ is proportional to the distance between donor and acceptor involved in the process $(R)$ :

$$
W(R)=W_{\max } \exp \left(-\frac{2 R}{a_{D}}\right) .
$$

Here $W_{\max }$ is the transition rate in the limit $R \rightarrow 0$ and $a_{D}$ is the Bohr radius of a more weakly bound particle in the DAP. The time evolution of the luminescence intensity in the case of randomly distributed DAPs can be expressed as [20]

$$
\begin{aligned}
I(t) \propto & N \exp \left\{4 \pi N \int_{0}^{\infty}\left[\mathrm{e}^{-W(R) t}-1\right] R^{2} \mathrm{~d} R\right\} \\
& \times \int_{0}^{\infty} W(R) \mathrm{e}^{-W(R) t} R^{2} \mathrm{~d} R,
\end{aligned}
$$

where $N$ is the concentration of majority constituent in DAPs. Constant values $W_{\max }=3.5 \cdot 10^{7} \mathrm{~s}^{-1}, N=$ $4 \cdot 10^{17} \mathrm{~cm}^{-3}$, and $a_{D}=2.4 \mathrm{~nm}$ were used in the fitting procedure. The time of decrease in intensity of this component by a factor of e was taken as the parameter

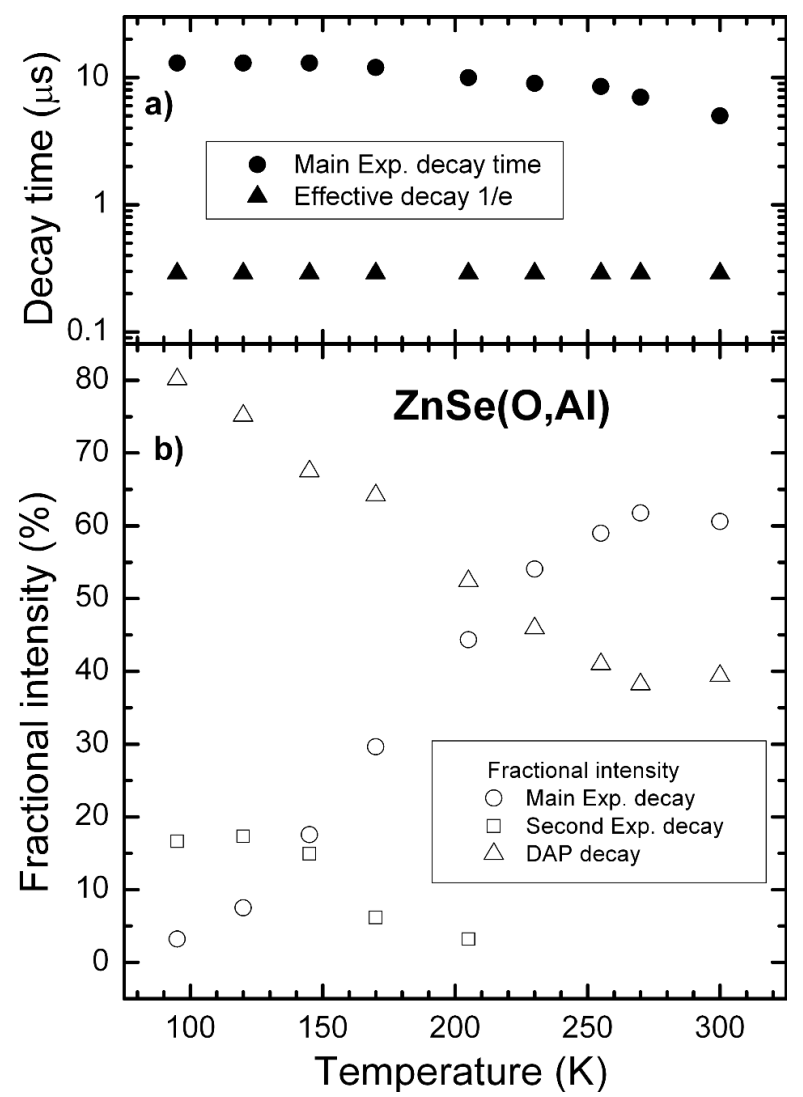

Fig. 3. (a) Photoluminescence decay times and (b) fractional intensities as functions of temperature for sample $\mathrm{ZnSe}(\mathrm{O}, \mathrm{Al})$. Closed circles depict the decay time of the main exponential decay component, closed triangles correspond to effective decay time of DAP recombination. Open triangles, circles, and squares depict the fractional intensities of DAP, main, and second exponential decay components, respectively.

characterizing the decay rate, though the decay is nonexponential.

To fit the experimental data in the entire temperature range under study, the second decay component was used in the decay function. This component was exponential. To achieve a better fitting at low temperatures, one more exponential component was necessary, but its relative weight with respect to those of the two first components was quite small, thus we neglect this contribution in the following discussion. An example of the fit of the phase shift frequency dependence is presented in Fig. 2.

The photoluminescence decay parameters as functions of temperature are depicted in Fig. 3. The decay time of the main exponential decay is indicated as closed circles (Fig. 3(a)). Closed triangles correspond to the effective DAP decay time, which is calculated as the time necessary for intensity of DAP component to decay by a factor of e. The fractional intensities of exponential (open circles and squares) and DAP (open trian- 
gles) are depicted in Fig. 3(b). The intensity of the DAP recombination component decreases dramatically and gives way to the main exponential component with the temperature raised. Meanwhile, the increase of temperature from 95 to $300 \mathrm{~K}$ results in a drop of the PL intensity only by a factor of four. Moreover, the decay times (see Fig. 3(a)) also do not show significant variations with increasing temperature: the effective decay time for DAP component remains constant at $\sim 0.29 \mu \mathrm{s}$, the decay time of the exponential component decreases by a factor of $\sim 2.5$. This is an indication of small influence of nonradiative recombination even at room temperature. Thus, the temperature-dependent competition of recombination components is probably caused by thermally activated redistribution of photoexcited carriers between two different types of defect-related recombination centres.

\section{Conclusions}

In conclusion, comparison of photoluminescence properties of isoelectronically doped $\mathrm{ZnSe}(\mathrm{Te})$, $\mathrm{ZnSe}(\mathrm{O})$, and $\mathrm{ZnSe}(\mathrm{O}, \mathrm{Al})$ shows that doping of $\mathrm{ZnSe}$ with oxygen and, especially, with oxygen and aluminium is favourable in respect of doping with tellurium to achieve a higher output of defect-related emission peaked at $\sim 600 \mathrm{~nm}$. PL decay can be described by two components: donor-acceptor-pair recombination component decays with characteristic time of $\sim 0.29 \mu \mathrm{s}$ within the entire temperature range under study (95-300 K), the second component decays exponentially with the decay time slightly decreasing from $12 \mu \mathrm{s}$ at $95 \mathrm{~K}$ down to $5.5 \mu \mathrm{s}$ at room temperature. The results evidence a rather small influence of nonradiative recombination up to room temperature and demonstrate temperature-dependent competition between donor-acceptor-pair-type and exponential luminescence decay components in the luminescence band used as the emission band in $\mathrm{ZnSe}$ scintillator detectors.

\section{Acknowledgements}

The work has been partially supported by INTAS project No. 05-104-7519, Joint Lithuanian-Ukrainian Research and Development Program, and the Lithuanian State Science and Studies Foundation (project No. V-20/2008).

\section{References}

[1] L.V. Atroshchenko, S.F. Burachas, L.P. Gal'chinetskii, B.V. Grinev, V.D. Ryzhikov, and N.G. Starzhinskiy, Scintillator Crystals and Detectors of Ionizing Radiation on Their Basis (Naukova Dumka, Kiev, 1998) p. 312 [in Russian].

[2] P. Schotanus, P. Dorenbos, and V.D. Ryzhikov, Detection of $\mathrm{CdS}(\mathrm{Te})$ and $\mathrm{ZnSe}(\mathrm{Te})$ scintillation light with silicon photodiodes, IEEE Trans. Nucl. Sci. 39(4), 546-550 (1992).

[3] V. Ryzhikov, V. Chernikov, L. Gal'chinetskii, S. Galkin, E. Lisetskaya, A. Opolonin, and V. Volkov, The use of semiconductor scintillation crystals A(II)B(VI) in radiation instruments, J. Cryst. Growth 197(3), 655-658 (1999).

[4] V. Ryzhikov, L. Gal'chinetskii, K. Katrunov, E. Lisetskaya, V. Gavriluk, O. Zelenskaya, N. Starzhynskiy, and V. Chernikov, Composite detector for mixed radiations based on CsI(Tl) and dispersions of small $\mathrm{ZnSe}(\mathrm{Te})$ crystals, Nucl. Instrum. Methods A 540(23), 395-402 (2005).

[5] Y.K. Kim, J.K. Kim, W.G. Lee, S.Y. Kim, B.I. Kim, J.H. Ha, N. Starzhinskiy, V. Ryzhikov, and B. Grinyov, Properties of semiconductor scintillator ZnSe: O, Nucl. Instrum. Methods A 580(1), 258-261 (2007).

[6] R. Baltramiejunas, V.D. Ryzhikov, V. Gavryushin, A. Kazlauskas, G. Raciukaitis, V.I. Silin, D. Juodzbalis, and V. Stepankevicius, Luminescent and nonlinear spectroscopy of recombination centers in isovalent doped $\mathrm{ZnSe}$ : Te crystals, J. Lumin. 52(1-4), 71-81 (1992).

[7] L.V. Atroshchenko, S.N. Galkin, I.A. Rybalka, E.F. Voronkin, A.I. Lalayants, V.D. Ryzhikov, and A.G. Fedorov, Effects of tellurium concentration on the structure of melt-grown ZnSe crystals, Nucl. Instrum. Methods A 537(1-2), 211-214 (2005).

[8] V.D. Ryzhikov, N.G. Starzhinskiy, L.P. Gal'chinetskii, and V.I. Silin, in: Functional Materials and Technology (Kharkov, 2001), p. 76.

[9] V.D. Ryzhikov, N.G. Starzhinskiy, L.P. Gal'chinetskii, V.I. Silin, G. Tamulaitis, and E.K. Lisetskaya, The role of oxygen in formation of radiative recombination centers in $\mathrm{ZnSe}_{1-x} \mathrm{Te}_{x}$ crystals, Int. J. Inorg. Mater. 3(8), 1227-1229 (2001).

[10] V. Ryzhikov, G. Tamulaitis, N. Starzhinskiy, L. Gal'chinetskii, A. Novickovas, and K. Kazlauskas, Luminescence dynamics in $\mathrm{ZnSeTe}$ scintillators, J. Lumin. 101(1-2), 45-53 (2003).

[11] O.V. Vakulenko, V.N. Kravchenko, V.D. Ryzhikov, V.I. Silin, and N.G. Starzhinskiy, Effect of superstoichiometric components on the spectral and kinetic characteristics of the luminescence of $\mathrm{ZnSe}$ crystals with isovalent impurities, Semicond. 31(10), 10411045 (1997) [in Russian: Fiz. Tekh. Poluprovodn. 31(10), 1211-1215 (1997)]. 
[12] V.D. Ryzhikov, B.V. Grinyov, E.N. Pirogov et al., Analysis of thermal treatment effects upon opticoluminescent and scintillation characteristics of oxide and chalcogenide crystals, Nucl. Instrum. Methods A 537(1-2), 223-227 (2005).

[13] K.H. Lee, L.S. Dang, and G.D. Watkins, Optically detected magnetic resonance of the zinc vacancy in $\mathrm{ZnSe}$, Solid State Commun. 35(7), 527-530 (1980).

[14] D.J. Dunstan, J.E. Nicholls, B.C. Cavenett, and J.J. Davies, Zinc vacancy-associated defects and donoracceptor recombination in $\mathrm{ZnSe}$, J. Phys. C 13(34), 6409-6419 (1980).

[15] H.G. Grimmeis, C. Ovren, W. Ludwig, and R. Mach, Identification of deep centers in ZnSe, J. Appl. Phys. 48(12), 5122-5126 (1977).

[16] J.Z. Zheng, J.W. Allen, D.E. Spence, W.E. Sleat, and W. Sibbett, Decay time of the blue luminescence in $\mathrm{ZnSe}$ at room-temperature, Appl. Phys. Lett. 62(1), 63-
65 (1993).

[17] A. Hoffmann, R. Heitz, B. Lummer, Ch. Fricke, V. Kutzer, I. Broser, W. Taudt, G. Gleitsmann, and M. Heuken, Incorporation of nitrogen in $\mathrm{ZnSe}$ grown by metalorganic vapour-phase epitaxy, J. Cryst. Growth 138(1-4), 379-384 (1994).

[18] H. Wang, K.S. Wong, B.A. Foreman, Z.Y. Yang, and G.K.L. Wong, One- and two-photon-excited timeresolved photoluminescence investigations of bulk and surface recombination dynamics in $\mathrm{ZnSe}$, J. Appl. Phys. 83(9), 4773-4776 (1998).

[19] J.R. Lakowicz, Principles of Fluorescence Spectroscopy (Kluwer Academic/ Plenum, New York, 1999).

[20] D.G. Thomas, J.J. Hopfield, and W.M. Augustyniak, Kinetics of radiative recombination at randomly distributed donors and acceptors, Phys. Rev. 140(1A), A202-A220 (1965).

\title{
ZnSe SCINTILIATORIŲ LIUMINESCENCIJOS TYRIMAI DAŽNINĖS SKYROS METODU
}

\author{
P. Vitta ${ }^{\text {a }}$, G. Tamulaitis ${ }^{\text {a }}$, D. Shevchenko ${ }^{\text {a }}$, A. Žukauskas ${ }^{\text {a }}$, N. Starzhinskiy ${ }^{\text {b }}$, K. Katrunov ${ }^{\text {b }}$, V. Ryzhikov ${ }^{\text {b }}$ \\ ${ }^{\text {a } V i l n i a u s ~ u n i v e r s i t e t o ~ M e d z ̌ i a g o t y r o s ~ i r ~ t a i k o m u j u ̨ ~ m o k s l u ̨ ~ i n s t i t u t a s, ~ V i l n i u s, ~ L i e t u v a ~}$ \\ ${ }^{\mathrm{b}}$ Ukrainos NMA Scintiliaciniu medžiagu insitutas, Charkovas, Ukraina
}

\section{Santrauka}

Cinko selenidas ir jo daugiasluoksniai dariniai prieš dešimtmeti buvo intensyviai tyrinėjami siekiant sukurti mèlynus šviestukus ir lazerinius diodus. Šie bandymai buvo nesėkmingi dèl nepakankamo ZnSe heterodarinių ilgaamžiškumo. Tuo tarpu tūrinių ZnSe kristalų savybės yra stabilios, jie atsparūs drègmei ir jonizuojančiajai spinduliuotei. Tinkamai parinkus auginimo ir šiluminio apdorojimo sąlygas, galima išauginti ZnSe monokristalus, pasižyminčius intensyvia priemaišine liuminescencija, kuri silpnai sugeriama kristale, nes jos spektras yra ZnSe draustiniame tarpe. Ši liuminescencija jau sèkmingai panaudota scintiliaciniuose Rentgeno spinduliu ir jonizuojančiosios spinduliuotès jutikliuose.

Buvo tiriama izovalentinių priemaišų ịtaka ZnSe scintiliacinių kristalų liuminescencijos našumui ir šios liuminescencijos laikinès charakteristikos. Tirti ZnSe kristalai su dažniausiai naudojama izovalentine telūro priemaiša ir deguonimi bei deguonies su aliuminiu priemaišomis. Parodyta, kad deguonis efektyviau nei telūras skatina priemaišinių spindulinès rekombinacijos centrų formavimą. Didžiausias šios liuminescencijos našumas gautas $\mathrm{ZnSe}(\mathrm{Al}, \mathrm{O})$ kristaluose.

Liuminescencijos gesimo matavimai buvo atliekami mažo nepusiausvirųjų krūvininkų tankio režimu, kuris atitinka įprastą didelio jautrumo scintiliatorių darbo režimą. Tam naudota dažninès skyros metodika. Matavimai atlikti plačiame temperatūros intervale, stebèta donorų ir akceptorių rekombinacijai būdingo gesimo ir eksponentinio gesimo konkurencija. 